\title{
Insights into the impact of genetic variation in bitter taste sensitivity on young children's acceptance of vegetables and body mass index: an update until 2010
}

\author{
Paloma Rohlfs Domínguez ${ }^{1,2,3 *}$ \\ ${ }^{1}$ Department of Psychology and Anthropology, University of Extremadura, Spain \\ ${ }^{2}$ Department of Social Psychology and Methodology of Behavior, Basque Country- Euskalherriko Univertsitatea, Spain \\ ${ }^{3}$ Department of Experimental Psychology and Behavioral Physiology, University of Granada, Spain
}

\begin{abstract}
Vegetable consumption by young children does not meet national recommendations in either the United States or in Europe due in part to the bitter taste of vegetables. Cruciferous vegetables contain natural bitter-tasting substances that share the same chemical structure as phenylthiocarbamide (PTC) and its chemical derivative 6-n-propylthiouracil (PROP). The degree to which the bitter taste from PTC/PROP is perceived is genetically determined and individual food likes are associated with this genetic trait, especially in children. The ability to taste calcium $(\mathrm{Ca})$ influences the ability to taste the bitterness of vegetables in adults but this influence has not yet been studied in young children. Therefore, a critical analysis of the impact of young children's PTC/PROP taster status on their vegetable acceptance is required. Furthermore, evidence that young children typically develop obesity because of their high consumption of high calorie content foods instead of vegetables requires critical analysis of the same impact on young children's body mass index (BMI). This two-fold analysis found conflicting results in studies that have examined ad hoc the relationship between PTC/PROP taste sensitivity and young children's vegetable acceptance and BMI. Genetic variation in the ability of young children to taste $\mathrm{Ca}$ might modulate the relationship between PTC/PROP taste sensitivity and vegetable acceptance in young children while socioeconomic status (SES) might modulate the relationship between PTC/PROP taste sensitivity and BMI. Thus, further research on these possible modulations is recommended.
\end{abstract}

\begin{abstract}
Abbreviations: AAI: Alanine, Alanine and Isoleucine; AAV: Alanine, Alanine and Valine; AVI: Alanine, Valine and Isoleucine; BMI: Body Mass Index; C: Calcium; CD36: Cluster of Differentiation 36; Gpcrs: G-Protein Coupled Receptors; PAV: Proline, Alenine and Valine; PKD1L3: Polycystic Kidney Disease 1-Like 3; PKD2L1: Polycystic Kidney Disease 2-Like 1; PRO: 6-N-Propylthiouracil; PTC: Phenylthiocarbamide; PVI: Proline, Valine and Isoleucine; SES: Socio Economic Status; TAS2R38: Taste Receptor 2 Member 38; TAS1R3: Taste Receptor 1 Member 3
\end{abstract}

\section{Introduction}

The taste of a food is the main determinant of food likes and dislikes in humans [1] and, especially in children, of food choices and food consumption [2-5]. This principle is based on the strong correlations between alimentary preferences and consumption that have been found in research on human nutrition [6] and is of importance when dealing with vegetable intake [7-9]. Indeed, it has been established that humans are universally predisposed at birth to like sweet tastes and reject bitter ones [10-12]. For newborns, sweetness is synonymous with a "good" taste of food, while bitterness signifies a "bad" taste of food. The differentiated pattern of intense facial expressions, already found in preterm and full term newborns, in response to those different flavors confirms this natural human characteristic [13-16]. Furthermore, several authors have suggested that this natural liking for sweetness and rejection for bitterness is a response that provides an evolutionary advantage by favoring the satisfaction of two needs: an adequate intake of calories from nutrient foods and a protection against food poisoning derived from the ingestion of toxic substances which typically taste bitter, such as some xenobiotica-related substances [17-20]. This bipolar taste-based food classification constitutes an instinctively programmed criterion for food acceptance, which enhances satisfaction of both mentioned needs [21] and thus promotes survival.

It has also been established that the extent to which a taste is perceived as sweet or bitter depends, among other factors, on the individually programmed genetic sensitivity to tastes, which influences whether a food is liked or rejected [22]. That means that taste sensitivity is a hereditary trait and that different individuals perceive tastes per their differentiated inherited ability to taste gustatory stimuli [23]. Since there is genetic variation in taste sensitivity, the natural human attraction to sweet, and withdrawal from bitter tastes is an issue of the differentiated degree to which a person is genetically predisposed to perceive a sweet or a bitter taste as "good" or "bad", compared to other persons, rather than a question of universal tendencies that characterize human taste and affect all humans equally. Thus, individuals live together in separate taste-related sensory worlds.

The most studied case of genetic variation in taste sensitivity concerns the bitter taste of PTC and its derivate PROP [24]. Knowledge

Correspondence to: Paloma Rohlfs Domínguez, Department of Psychology and Anthropology, University of Extremadura, Spain and Department of Social Psychology and Methodology of Behavior, Basque Country- Euskalherriko Univertsitatea, Spain, Tel: 927257000; E-mail: palomaroh@unex.es

Key words: young children, vegetable consumption, PTC/PROP; taste sensitivity, genetics

Received: October 20, 2016; Accepted: October 24, 2016; Published: January 2, 2017 

update until 2010

in this issue has been gained through in vitro studies and through the Human Genome Project, which aimed to identify human structural genes [25]. Indeed, both approaches have provided valuable information regarding the possible genes that underly individual variability in bitter gustatory perception and have led to the discovery of the TAS2R38 gene (and its high polymorphism degree) as the responsible gene for that individual variability $[26,27]$. Meanwhile, genetic variation in sensitivity to calcium $(\mathrm{Ca})$ has been found with the taste receptor gene TAS1R3 explaining 7-13\% of the phenotypic variation in the preference for $\mathrm{Ca}$ and magnesium $[28,29]$. A strong correlation has been observed between sensitivity to $\mathrm{Ca}$ and the perception of the bitter taste from vegetables in animals and adult humans [30]. Furthermore, there is genetic variation in human sweet and umami taste receptors, which is associated with the taste receptor gene TAS1R [31], while PKD1L3 and PKD2L1 have been proposed as candidate sour taste receptors [32], CD36 as a candidate fat taste receptor [33], and the amiloride-sensitive epithelial sodium channel (EnaC) as a candidate salt taste receptor [34].

Based on the genetic variation in bitter taste sensitivity, individuals who are sensitive to PTC/PROP can be classified as being tasters, medium tasters or even supertasters, while those not sensitive to these substances can be classified as non-tasters [35]. Furthermore, a heightened sensitivity to the chemical compounds PTC and PROP has been associated with a reduced liking for bitter-tasting foods, such as cruciferous, green and high glucosinolate content vegetables, high fat content foods, green tea, soy products, alcohol and foods with a general strong taste, such as sharp cheeses [36-40]. The contrary pattern of liking is observed in individuals with PTC and PROP insensitivity, as nontasters are more likely to prefer edibles with these sensory properties [41]. Therefore, food intake and food choices may be influenced by this inherited trait $[38,42,43]$.

Taste ability decreases as individuals advance in age [44,45]. In the specific case of the ability to taste PTC or PROP, changes throughout the life span have been reported as a function of age. While it is high in young children, it progressively diminishes as individuals become mature and age [46-48]. Similarly, the association between PTC/ PROP sensitivity and food preferences has been shown to be more pronounced in children than in adults $[48,49]$, although experience may modify children's eating behavior patterns [50].

Children typically reject vegetables $[9,51,52]$ and vegetables are their least preferred kind of food [53,54]. This rejection has been mainly attributed to the bitter taste from vegetables [55-57]. Indeed, natural bitter substances from many cruciferous vegetables, which are usually glucosinolates, isothiocyanates and goitrin, share the same chemical group as PTC and PROP, namely $\mathrm{N}-\mathrm{C}=\mathrm{S}$ [58-60], and therefore taste bitter. Furthermore, high correlations between low liking rates for vegetables and low vegetable intake in young children have been observed [61,62]. It is not surprising then that vegetable consumption in young children does not meet national recommendations in the United States [62-65]. This is especially worrying since vegetable consumption in young children counteracts childhood obesity [66], one of the most serious public health problems throughout the world $[67,68]$ and prevents development of cancer and vascular disease in adulthood [69-71]. Furthermore, young childhood is the life phase in which preferences for foods, including vegetables, and eating habits are most likely to be established, and thus determines positive or negative eating behavior at least until young adulthood [72,73].

Young children typically prefer, and tend to consume, sweet and snack foods, instead of vegetables [74-76]. These eating habits have been observed to produce childhood obesity [77]. Children who prefer fruits and vegetables are, in turn, less likely to become overweight [66].

Since perception of the bitter taste of foods is genetically determined and since food preferences and eating habits are established in young childhood and maintained in adulthood [72,73], a review of studies in which the impact of young children's PTC/PROP taste sensitivity on their liking for vegetables has been examined ad hoc [78] is warranted. On the other hand, since current young children's eating behavior typically leads to obesity [43], a review of studies investigating the same impact on BMI (weight/height ${ }^{2}$ ) in young children is also warranted. Therefore, the present review is mainly concerned with a critical discussion of the involvement of genetic variation in PTC/PROP taster status in both young children's acceptance of vegetables and their BMI. Based on Goldstein et al. [47], young children will be here considered as being 6 years-old or younger. The studies reviewed here were published at the latest in 2010. Firstly, however, a review of the history of research on genetic variation in PTC/PROP sensitivity and its association with human food likes and dislikes will be presented as well.

\section{The discovery of genetic variation in PTC taste sensi- tivity and the consequent research on genetic determi- nants of taste}

Bitter taste constitutes the original focus of the study of the genetic variation in taste sensitivity and goes back to Fox's discovery in 1931 that there is a universal bipolar distribution of individuals based on their sensitivity to the bitter taste of the chemical compound PTC. Specifically, he found that some persons perceived PTC as bitter, while some others perceived it as tasteless [79]. This discovery was serendipitous in nature in that Fox was preparing PTC in his laboratory when the crystals spread through the air and were unavoidably tasted by him and his colleague (Dr. C.R. Noller). Interestingly, the crystals tasted bitter to Dr. Noller, while they had no taste for Dr. Fox. They knew that PTC contained the chemical group $\mathrm{N}-\mathrm{C}=\mathrm{S}$ that had been previously described by Berlinerblau [80] as being quite bitter. Dr. Fox then began to explore this gustatory difference across different populations and concluded that, regardless of any demographical variable, there was a universal bimodal distribution of individuals in relation to their perception of the bitter taste of the mentioned substances -tasters and non-tasters or taste blinds-, and therefore concluded the genetic origin of that distribution $[79,81]$.

Numerous subsequent efforts aimed to ascertain the specific genetic contribution to this variability in the perception of the bitter taste. By means of family studies, it was soon proposed that taste sensitivity or insensitivity to PTC was inherited as a two-allele trait within a simple Mendelian model of inheritance, with these two alleles being recessive in the case of the inherited insensitivity to PTC $[82,83]$. However, the responsible gene and its chromosomal location were then unknown. The Mendelian model of taste sensitivity inheritance proposes that PTC sensitivity relies on the dominant allele $\mathrm{T}$, so that tasters inherit their taste efficiency as one ( $\mathrm{tT} / \mathrm{Tt}$ ) or two-dominantallele trait (TT), while non tasters inherit their taste deficiency as a recessive insensitive allele trait (tt) $[34,84]$. Subsequent family studies observed robust correlations between the sensitivity degree to PTC of parents and that of their children $[23,85,86]$, thus reinforcing Snyder's and Blakeslee's hypothesis of a Mendelian model of inheritance of bitter taste sensitivity.

However, the original simple Mendelian model of PTC-related sensitivity inheritance could not explain the results of several other 

update until 2010

studies. For example, other genetic issues and non-genetic factors were also demonstrated to have an impact on the inherited taste sensitivity to PTC $[27,84,87]$. Furthermore, it was found that children of non-taster parents were taster, which contradicts an explanation based in a onelocus model [88] and is better explained by alternative models, such as two-locus and multiple loci models [89]. In view of these conflicting results, the search for the gene responsible for the variation in PTC taste ability became the priority objective of the first linkage studies on this trait, although these efforts added more conflicting results to the debate $[26,27]$. For example, some of these studies demonstrated linkage to the chromosome 7q $[90,91]$, while a subsequent study didn't replicate this finding [92] and a third showed linkage to the chromosome 5q [93].

The controversy derived from those conflicting results stimulated further research on the topic through linkage studies and resulted in the publication of two significant discoveries. The Utah family linkage study [94] found involvement of a single major locus in chromosome $7 \mathrm{q}$, as the main candidate gene for the variation in PTC-related bitter taste perception, although a second gene located on chromosome $16 \mathrm{p}$ appeared to be responsible for that variation in some of the studied families $(\mathrm{n}=26)$. Meanwhile, Kim et al. [95] reported the existence of a gene within chromosome $7 \mathrm{q}$, designated as TAS2R38, as being responsible for individual variation in gustatory sensitivity to PTC [95]. Moreover, Kim et al. [95] found the implication of three functional alleles of TAS2R38 in the variation of PTC perception as a result of the linkage analysis of the participating human families. These three alleles configure two main different haplotypes (PAV and AVI), also called genotypes. A haplotype consists of a group of alleles that tend to be inherited together [96]. These haplotypes are different from each other because of the polymorphic nature of their corresponding constituent amino-acids, as these amino-acids vary at three positions: 49 (alanine or proline), 262 (valine or alanine) and 296 (isoleucine or valine) [95].

The corresponding phenotype of the PAV haplotype is described as the major taster form and the phenotype of the AVI haplotype is described as the major non-taster form. Individuals carrying twice the PAV haplotype (PAV/PAV) are the most sensitive to PTC, individuals who carry both kinds of haplotypes (PAV/AVI) have an intermediate sensitivity $[48,97]$, and those homozygous for AVI (AVI/AVI) are the least sensitive. Furthermore, different combinations of amino acids at those positions (haplotypes), such as AAI, AAV, and PVI yield a greater range of PTC taste sensitivities $[34,95,98]$ in addition to the two most frequent combinations. The bitter-taste receptor gene TAS2R38 and its genotypes have also been found to be responsible for individual variation in gustatory sensitivity to the bitter taste of glucosinolatecontaining cruciferous vegetables -a natural kind of food-, such as turnip or broccoli [99], besides PTC, thus providing evidence to the hypothesized natural selection of the sensitivity to the bitter taste as a via to detect toxins within foods.

The TAS2R38 gene belongs to the TAS2Rs family, also referred as Ht2Rs, of human bitter taste receptor genes [100]. "TAS" is associated with a taste receptor gene while "2" indicates a bitter taste gene [101]. The human TAS2Rs family consists of 25 bitter taste receptor genes, which are grouped within the chromosomes $5 \mathrm{p}, 7 \mathrm{q}$ and $12 \mathrm{p}$, and with TAS2R38 located on chromosome 7q $[95,101]$.

It is assumed that each of the human TAS2Rs may be involved in the recognition of a vast range of similarly structured bitter substances, thus responding to a great diversity of potentially harmful compounds [12], although there is also at least one bitter taste receptor, namely hTAS2R14, which is activated in response to structurally diverse natural bitter compounds [20,102].

While TAS2Rs genes produce bitter receptors, TAS1Rs produce sweet and umami receptors [27]. Salty and sour tastes are mediated by ion channels serving as receptors [12]. In humans, TAS2Rs and TAS1Rs constitute the two most known gene families for encoding gustatory receptors residing on the surface of taste cells within the taste buds of the tongue, called GPCRs) $[100,103]$. GPCRs mediate the sweet, bitter and umami tastes by means of their expression in taste cells within taste buds [27]. Once GPCRs come into contact with watersoluble taste molecules, taste cells are activated and taste transduction takes place, which is followed by neural taste processing and taste perception [12,104]. There are multiple bitter taste receptors, through which humans can identify multiple bitter compounds, so that bitter taste transduction is dependent on the specific bitter compounds [105].

The existence of the two main forms of phenotypic expression of the TAS2R38 gene, namely the major taster form and the major nontaster form, has been consistently observed throughout the world. Indeed, several studies have examined the ratio of tasters to non-tasters worldwide [24] yielding the conclusion that $75 \%$ of the population perceive bitterness intensively, while the remainding percentage of the population is less sensitive to it $[26,43]$. Furthermore, there are some differences in such proportions between regions. For example, while in the United States and Europe, $30 \%$ of the adult caucasian population is insensitive [106-109], in West Africa only 3\% of the population is insensitive [43], and in Japan, China and Sub-Saharan Africa, 10$20 \%$ is insensitive [24]. In India, $40 \%$ or more of the population is insensitive $[43,106]$, although this proportion varies between Indian regions [110]. Interestingly, there is an absence of bitter non-tasters in a small community of Brazilian Indians [111].

Other TAS2Rs genes show a similar variation to that of TAS2R38, although variation is regional rather than worldwide [29]. This is the case, for example, of the human bitter taste receptor TAS2R16, which encodes GPCRs in response to amygdalin, salicin and many bitter $\beta$-glucopyranosides, which was the first bitter taste receptor gene to be identified as being responsible for sensitivity to natural bitter compounds [112-114]. Specifically, while both its alleles, namely the less sensitive and the more sensitive, coexist with high frequency in African populations, only the more sensitive allele is observed in most other populations $[20,113]$.

This regional diversification of bitterness sensitivity and insensitive might be the product of Darwinian adaptation to the regionally differentiated existing vegetation [115]. That means that genes would have evolved that favor adaptation to regional conditions that are specifically related to the presence of toxins in vegetables [22]. Moreover, balancing natural selection of the two previously mentioned main forms of genetic variation of bitter taste sensitivity (PAV for tasters and AVI for non-tasters) appears to be the most convincing mechanism through which that genetic variation can be explained $[27,34,98,116]$. The main evidence supporting this mechanism refers to the demonstrated fact that the non-taster allele doesn't derive from mutation of the normal taster allele [27]. At the same time, this fact has yielded the hypothesis that the AVI allele might encode a functional receptor for other, yet to be identified toxic bitter substances [34] that may be present in the surrounding environment. Alternatively, the other two proposed explanatory mechanisms for the high frequency of the non-taster allele are genetic drift, on the one hand, and population subdivision, on the other [27]. While genetic drift refers to hypothesized random fluctuations as a cause of variation in gene 

update until 2010

frequencies, population subdivision refers to the hypothesis that the high frequency of the non-taster allele is limited to one population. However, both of these proposals have been scientifically ruled out because the two major bitter taste haplotypes are too common in all populations [27].

The identification of TAS2R38 as the single gene responsible for the phenotypic variation in PTC sensitivity confirmed the Mendelian model of inheritance for most of the bimodal phenotypic expression of PTC-related bitter perception, although not as a simple recessive model for the PTC-related [27]. Nevertheless, the finding from Drayna et al. [94] that chromosome 16p is implicated in variation in bitter taste sensitivity, in addition to chromosome $7 \mathrm{q}$, has led several authors to suggest that PTC's genetics can be explained by a mixed model, based on a Mendelian and a complex trait $[26,27]$. However, recent research has found a robust correlation between the calcium (Ca) content of certain vegetables and the perception of their bitter taste in humans $(r=0.93)$. This has been supported through animal research with rats of different genetically determined sensitivity to $\mathrm{Ca}$ and choice tests between vegetables with a high $\mathrm{Ca}$ content and vegetables with low $\mathrm{Ca}$ content [30]. Furthermore, it has been shown that the taste receptor TAS1R3 explains a $7-13 \%$ of the phenotypic variation in the preference for $\mathrm{Ca}$ and magnesium $[28,29]$. Thus, individual variation in bitter taste perception might be due to a combination of genes, rather than one gene, although more research is needed to establish the role of genetic variation in Ca sensitivity on bitter perception.

Apart from PTC, its derivative PROP has also been described as showing a differentiated distribution within and across populations [116]. PROP, like PTC, contains the typical chemical structure of "thioureas" $-\mathrm{N}-\mathrm{C}=\mathrm{S}$-, which tastes bitter $[104,116]$. Furthermore, PROP taster status was found to be significantly correlated with PTC taster status $[117,118]$. The question that then emerged was whether PROP and other substances with the same chemical structure and with bimodal distribution were also perceived through the operation of the same taste receptor [34]. In this sense, it was confirmed via in vivo and in vitro studies that the taste receptor TAS2R38 also mediates responses to PROP, although it has been found that PTC matches with it better $[27,100]$. Thus, the TAS2R38 receptor responds to all bitter substances if they belong to the thioureas.

Genetic studies on taste then began to use PROP frequently as a substitute for the potentially toxic effects and the sulfur odorous PTC $[119,120]$, and therefore most of the worldwide observations regarding genetic variation in bitter taste sensitivity have been derived from studies in which PROP has been used, instead of PTC. However, humans do not perceive both compounds identically and they are not interchangeable. For example, bitterness perception thresholds for PTC are lower than for PROP and the PTC's perceptive spectrum is more extensive than is PROP's [101]. Additionally, the distribution of the phenotypic expression of bitterness sensitivity to PROP within the population is "tri-modal" rather than bimodal, as cases of PROP supertasters have been found $[35,121,122]$. Furthermore, it has been shown that the density of taste receptors in the tongue -taste buds contained within fungiform papillae- correlates significantly with the perceived bitterness intensity of PROP $[27,96,101]$ with PROP supertasters showing the highest rates of fungiform papillae and thus perceiving the most extreme degree of bitterness [123,124]. Supertasters also perceive the most intense thermal and tactile sensations derived from foods, such as food creaminess, viscosity or burn within the oral cavity because pain and touch neurons also innervate fungiform papillae [125]. Interestingly, a gender effect on the density of taste buds has been observed with women having higher number of these papillae and taste buds than men $[35,121,122]$. Consequently, most adult tasters and supertasters are women [126]. This gender-related distribution of tasters and non-tasters is not observed in young children [49,100,127], but from the beginning of puberty onwards $[41,128]$. Thus, based on Drayna [27], phenotypic distribution of taste sensitivity to PROP, especially the supertaster phenotype, is influenced by other factors in addition to genetic control.

\section{Methodology for the evaluation Of PTC/PROP status}

There is no standardized protocol for the evaluation of PTC/PROP sensitivity status. On the contrary, a variety of methods have been used across research work on the topic to obtain reliable measures of individuals' taste sensitivity to PTC/PROP compounds. A profound analysis of the psychophysical methods is beyond the scope of this text, and readers are recommended to review comprehensive publications on this topic [125,129-131]. Furthermore, the work of Lawless [119] shows an in-depth comparison of the effectiveness of different methods in making that evaluation. A short description of the main methods for the evaluation of PTC and PROP taster status will however be presented.

Research protocols examining differences in bitter taste perception and its genetic nature, prior to the discovery of the TAS2R38 gene, have included twins as subject samples or have used PTC/PROP screening tests [48]. The importance of twin designs relies on the a priori assumption that twin pairs, either monozygotic or dizygotic, live together under the same stimuli exposure conditions, so that any difference in taste perception is potentially attributed to differences of genetic nature [22]. Screening tests, on the other hand, can be classified into two global categories: threshold and supra threshold methods [100]. Both are aimed to establish individualized PTC/PROP detection thresholds by exposing participants to these substances using PTCsoaked filter papers placed on the tip of the tongue [132] or by them swallowing PTC content liquid forms. Threshold methods measure individuals' bimodal variation in PTC/PROP sensitivity based on their responses to single concentrations of these substances. Thus, subjects have only to affirm whether they perceive the taste solution or not, and thus they can be classified as either tasters or non-tasters [133]. Suprathreshold methods or Supra-threshold scaling techniques, introduced by Stevens [134], are based on the serial presentation of different PTC concentration samples and "forced choice blind tests" [26], so that further subdivisions of the degree to which subjects perceive PTC or PROP can be addressed and medium tasters and supertasters can be classified [84,123].

The discovery of the TAS2R38 gene has led to the possibility of measuring genetic variability in PTC/PROP sensitivity directly through genomic DNA extraction and allele genotypification of the TAS2R38 gene $[48,49]$. All these PTC/PROP taster status-related measurement techniques have been used with adults as well as with children as young as 3 years old [135].

\section{Genetic variation in PTC/PROP taster status and its as- sociation with perception of different substances, other tastes and other oral sensations}

The main characteristic of PTC/PROP tasters is their ability to perceive low concentrations (i.e., $0.001 \mathrm{M}$ ) of any bitter compound as aversively bitter, as opposed to non-tasters, who either cannot taste the bitterness of that substance or would need high concentrations of it 

update until 2010

to be able to recognize the bitter taste [136]. Medium tasters perceive the bitterness of PTC/PROP with a lesser degree of aversion, than do tasters [137] and super tasters perceive an extreme bitter taste from PTC/PROP [100,137].

Examples of typically bitter-tasting substances, to which humans may respond differently as a function of their sensitivity to PTC/PROP, are: caffeine, urea and quinine [17,138-140], although Yokomukai, Cowart and Beauchamp [141] found no correlation between PROP sensitivity and urea or quinine. Furthermore, some authors have found that the intensity of the bitter taste of potassium chloride, sodium benzoate and potassium benzoate is also related to PROP taster status [142-145].

On the other hand, PTC/PROP sensitivity has been shown to be associated with sensitivity to other tastes. For example, PTC/ PROP tasters typically perceive the sweetness of low concentrations of sucrose and saccharin as intensively sweeter than non-tasters $[11,17,142,146,147]$. However, genetic sensitivity to PROP did not predict sweetness intensity ratings or hedonic response to sweetness for sucrose solutions in a subject sample of young females of different ethnic origin [148]. Citric acid has also been shown to be perceived as sourer by tasters than non-tasters [149] and sodium chloride as saltier $[42,150]$. Although PTC and PROP are not natural bitter chemical compounds of foods, genetic variability in perception of their tastes has been shown to be strongly correlated with taste sensitivity to other natural bitter and sweet compounds that are present in foods $[43,126,138,146]$. Furthermore, sensitivity to fat and creaminess of foods has also been observed to be correlated with PROP taster status $[151,152]$.

Several gustatory sensations, other than pure taste, have also been shown to be correlated with PTC/PROP status. For example, oral pain [78], oral irritation produced by citric acid [153] and the burning sensation caused by the capsaicin in chili peppers have been also shown to be perceived more intense by tasters than non-tasters $[17,154,155]$. Similarly, PROP tasters have been found to perceive the intensity of ethyl alcohol more strongly than non-tasters [156]. The vast variety of oral sensitivities which correlate with PTC/PROP taster status have led several authors to attribute a role of general oral marker to the PTC/ PROP taster status [101,157].

\section{Genetic variation of PTC/PROP taster status and its as- sociation with food likes and dislikes: age effects}

The importance of this genetically determined gustatory variability relies on the manifest effects it has on individuals' eating habits. The main effect is the establishment of individualized patterns of nutritional behavior, including food choices, preferences and intake patterns, because individuals' hedonic value of foods, and therefore food likes and dislikes, vary as a function of PTC/PROP taster status [105,125]. Some of the products that have been shown to be more disliked and less preferred by tasters than non-tasters are dairy products, such as milk or cheese, cruciferous vegetables, such as spinach, broccoli, and brussels sprouts alcohol $[17,78,158]$, and high-fat-content foods, sweets and meats $[42,106]$. Moreover, it has been shown that PTC/PROP tasters tend to dislike strong tasting foods in general and exhibit more food dislikes, while PTC/PROP non-tasters display higher acceptance of a greater variety of foods in adults $[159,160]$ as well as in children $[11,78,127,161,162]$.

Interestingly, the ability to taste PTC/PROP is heightened in young children and progressively decreases as people become older
$[46,47]$ and the association between PTC/PROP taster status and food likes and dislikes appears to be stronger in children than in adults [49]. Specifically, Mennella et al. [49] reported that children with high sensitivity to PROP, that is, with PAV/PAV genotypes, or with moderate sensitivity to PROP, that is, with PAV/AVI genotypes, prefer sweet beverages and foods more than children with less sensitivity to PROP, while no correspondence between TAS2R38 genotypes and sweet preferences was observed in adults. In agreement with these findings, it has also been reported that use of bitter-tasting foods increases with increasing age $[48,163,164]$.

Taste ability, in general, has been shown to diminish as an individual ages [44,45] and as consequence, taste perception of foods is compromised in older subjects when compared to young adults [165]. Causes of the decrease in ability to taste have been attributed to use of pharmaceuticals as well as to an age-related progressive lost of taste receptors [48]. These findings, along with the lack of an association between TAS2R38 genotypes and sweet preference in adults [49], have led some authors to suggest that, as individuals mature, cultural influences and physiological factors, such as the loss of taste receptors as people age, exert a more important influence on food preferences and intake than taste sensitivity-related genetic influences $[48,49]$. The strong genetic impact of PTC/PROP sensitivity on young children's food preferences can be overcome if enough repeated exposure -at least 8 days- to any food, including vegetables, is applied [166-169] and may last until, at least, young adulthood [72].

Based on these findings, we can conclude that the younger an individual is, the higher the impact of PTC/PROP taster status on that individual's food likes and dislikes will be. Furthermore, the more sensitive to the bitter taste a person is, the higher the proportion of foods that are disliked will be, while those less sensitive will prefer a wider spectrum of foods, and especially high-sugar- and high-fatcontent foods. However, see Drewnowski, Henderson and Cockroft [170] for a contrary point of view.

Sensitivity to other tastes, such as salty or sour tastes has not been found to be related to food likes or dislikes [17,171-173]. However, human genetic variation in sweet taste perception has recently been found, in addition to findings of strong correlations between the allelic polymorphism of TAS1R3 and sweet taste sensitivity to sucrose [174]. Further research is needed to ascertain if there is genetic variation in the perception status of other tastes, and therefore, its association with the hedonic value of foods, as well as possible age-related modulations.

\section{Impact degree of young children's PROP taste sensitiv- ity on their vegetable acceptance}

Several studies have examined ad hoc the relationship between PROP taste sensitivity and acceptance of bitter vegetables, such as cruciferous and non-cruciferous vegetables, in young children. Anliker et al. [78] conducted a study with children aged between five and seven and found no significant difference between PROP tasters and nontasters with regard to their liking of raw broccoli, cooked broccoli and raw spinach, which is a bitter-tasting vegetable from the chenopodiaceae vegetable family [59]. Tasters however, stated a lower preference for these vegetables than non-tasters in a food-preference questionnaire. Turnbull and Matisoo-Smith [144] observed that sensitivity to PROP predicted low acceptance of raw spinach in children aged between three and six, although this relationship was not found for raw and cooked broccoli. Another subsequent study conducted in four and five year-old children [127] concluded that PROP taster children reported a 

update until 2010

lower acceptance of raw broccoli than did non-taster children. Tepper and Steinmann [106] had previously observed this acceptance in children, although the data remain unpublished. Similar findings were replicated in a study of consumption of raw broccoli in three to four year-old children [175]. Furthermore, non-tasters ate more vegetables, including more raw bitter vegetables (cucumber, broccoli and black olives) than did tasters and ate more bitter than non-bitter vegetables (carrots and red peppers). These findings, taken as a whole, suggest an inverse relationship between PROP taste sensitivity and acceptance of vegetables in young children, although the strength of this relationship appears to be weak. This lack of robustness might exist because other genes as well as TAS2R38, such as TAS1R3 which has been shown to be responsible for variability in sensitivity to $\mathrm{Ca}$, and therefore to the bitter taste from vegetables in adults [28-30], might also influence young children's sensitivity to the bitter taste of vegetables. However, this possible explanation has not yet been studied and the genetic variability in sensitivity to $\mathrm{Ca}$ has not been taken into account in studies that have examined the association between bitter taste sensitivity and vegetable acceptance in young children. Since previous research points to an association between both parameters in 18-66-year-old subjects $(r=0.93)$ as well as in rats [28-30], it would be interesting to examine the role of genetic variation in Ca taste sensitivity in bitter taste perception of vegetables in young children. A combination of both of these traits might underlie the individualized pattern of responsiveness to the bitter taste of vegetables.

\section{Impact degree of young children's PROP taste sensitiv- ity on their BMI}

Studies examining the suspected association between PROP and BMI in young children have yielded conflicting results. Keller and Tepper [107] reported contradictory relationships between BMI and PROP status, according to gender, in four to five year-old children, as non-taster boys showed higher BMIs than taster boys, and taster girls showed higher BMIs than non-taster girls. Furthermore, in a sample of low-income three to six year-old children, a correlation between PROP taster status BMI z-scores was found and the prevalence of overweight children was higher in the taster group [108]. On the other hand, other studies have found no difference in weight or BMI as a function of PTC/PROP sensitivity status in the same age range of four to five years $[127,175]$. Goldstein et al. [41] in a study of pre-adolescent children (age=7-11 years), examined the hypothesis that PROP sensitivity might influence the eating behavior of young children, but that differences in body weight emerge later in development, and concluded that there was no association between PROP status and body weight in their subject sample. These conflicting findings suggest the existence of a confounding factor that might be exerting an influence on this relationship. Although Keller and Tepper [107] found a gender effect, this has never been replicated and gender is unlike to be such a confounding factor. SES is however, a more likely candidate. The rationale for this claim is offered by Lumeng et al. [108] who state that, with the exception of their own work in which subjects were of low SES, previous studies, such as those of Keller et al. [127], Keller and Tepper [107], and Bel and Tepper [175] were conducted with children of above average SES. Indeed, all children who participated in these studies were enrolled in the Rutgers University Nutritional Sciences Preschool, which is a very exclusive nutrition-related educational program of the State University of New Jersey that is focused on preschool children. Furthermore, Baranowski et al. [176] found a significant PROP sensitivity by SES interaction term $(\mathrm{P}=0.010)$ in children aged between nine and ten and adolescents aged between seventeen and eighteen, regardless any other demographical variable. Specifically, supertasters showed the largest BMI percentile and Z-score, but only among the children with highest SES. However, no study has yet considered SES as an independent variable in order to examine wether the relationship between PROP taster status and BMI could change as a function of an individual's SES in young children, that is, children aged 6-year-old or younger. Thus, future research examining this possible influence in young children is warranted.

\section{Conclusions and future research}

This review has aimed to critically discuss the role of genetic variation in bitter taste sensitivity in young children's vegetable acceptance and BMI and to achieve this aim, it was necessary to review the history of the study of genetic variation in PTC/PROP sensitivity and its association with with human food preferences. The scientific consensus is that genetic variation in PTC/PROP sensitivity determines human food likes and dislikes [157], and that this genetic determination is modulated by age. Specifically, a stronger genetic determination of food likes has been observed in young children than in adults and older individuals [48,49], which suggests that experience with foods modifies children's eating behavioral patterns [50]. Cultural and physiological conditions, combined with a negative correlation between age and chemo-sensitivity and taste sensitivity in particular $[48,84]$, may explain the lower impact of taste genetics on food preferences in mature and older subjects than in younger subjects.

The present review revealed that several reports conclude that young children's acceptance or rejection for vegetables depends on their genetically determined sensitivity to the bitter taste, which is indicated by the participants' PROP taster status. In these studies, young children characterized by a low PROP taste sensitivity accepted vegetables, especially raw broccoli and raw spinach, more readily than did children characterized by higher PROP taste sensitivity $[135,175]$. However, the strength of this dependency appears to be relative, in view of the conflicting results that have been observed. For example, while Keller et al. [127] found such a positive relationship regarding raw broccoli, Turnbull and Matisoo-Smith [135] did not. Furthermore, Anliker et al. [78] observed no differences between the liking ratings from tasters and non-tasters for individual vegetables (raw broccoli, cooked broccoli and spinach), although tasters ranked vegetables lower in an ordered preference ranking.

Apart from genetic variation in PROP taster status, genetic variation in $\mathrm{Ca}$ taster status has also been shown to exert an influence on the degree to which the bitterness from vegetables is perceived, and to explain individual differences in preference for vegetables in rats as well as adult humans [28-30]. However, this association has not been studied in young children. Therefore, it would be interesting to examine the association between young children's Ca taster status and their vegetable acceptance. The confirmation of this association would also confirm the claim that a probable combination of at least both of these genetic traits, instead of one unique genetic trait, may underlie the individualized pattern of responsiveness -sensitive vs. insensitive- to the bitter taste of vegetables, and therefore of preference for vegetables.

Since the bitter taste is the main determinant for rejection of consumption of vegetables in young children [56,57] and since the process of debittering vegetables through different mechanisms is possible $[177,178]$, food science would be well advised to make vegetables less bitter if young children are to increase their vegetable consumption. This recommendation is independent of the influence of genetic variation in bitter taste sensitivity on young children's vegetable 
Domínguez PR (2017) Insights into the impact of genetic variation in bitter taste sensitivity on young children's acceptance of vegetables and body mass index: an update until 2010

intake. However, natural bitter compounds occurring in vegetables, such as glucosinates are important cancer-preventive substances $[179,180]$, a solution to this dilemma is needed. Another strategy that can be applied to improve young children's vegetable consumption is the experience-related strategy of repeated exposure -without any reinforcement- to vegetables. Indeed, it has been shown that repeated exposure of young children to particular foods induces long lasting preferences for them $[72,167,169]$.

Conflicting results have been observed when examining the relationship between PROP taster status and BMI in young children. While some studies have found positive correlations, others have found negative correlations, gender-related contradictions, or have found no relationships at all. It has been suggested that confounding variables, such as SES might exert an influence on the mentioned relationship in old children, that is, children aged nine-year-old or older and adolescents [176]. However, SES has never been used as independent variable in studies examining the relationship between PROP and BMI in young children and all young children in whom that relationship has been studied have been of high SES. The exception is the study of Lumeng et al. [107], which examined the relationship between PROP taster status and BMI in a sample of low-income three to six year-old children. Thus, further research on SES as a possible factor modulating that in young children, is needed.

\section{Acknowledgement}

This work has been supported by the pre-doctoral fellowship of Junta de Andalucía and the project HUM-02763 of the University of Granada (Spain). I would like to thank Dr. R. Home, for his effort in reviewing this paper by making interesting suggestions on the content and refining the English language of the text.

\section{Conflict of interest}

There is no conflict of interest to declare.

\section{References}

1. Nasser J (2001) Taste, food intake and obesity. Obes Rev 2: 213-218. [Crossref]

2. Sorensen LB, Möller P, Flint A, Martens M, Raben A (2003) Effect of sensory perception of Foods on appetite and food intake: a review of studies on humans. Int $J$ Obes Relat Metab Disord 27: 1152-1166.

3. Zeinstra GG, Koelen M, Kok FJ, de Graaf C (2007) Cognitive development and children's perceptions of fruit and vegetables; a qualitative study. Int J Behav Nutr Phys Act 4: 30. [Crossref]

4. El-Sohemy A, Stewart L, Khataan N, Fontaine-Bisson B, Kwong P, et al. (2007) Nutrigenomics of taste - impact on food preferences and food production. Forum Nutr 60: 176-182. [Crossref]

5. Brug J, Tak NI, Te Velde SJ, Bere E, de Bourdeaudhuij I (2008) Taste preferences, liking and other factors related to fruit and vegetable intakes among schoolchildren: results from observational studies. Br J Nutr 99: S7-S14.

6. Baxter SD, Thompson WO, Davis HC (2000) Fourth-grade children's observed consumption of, and preferences for school lunch foods. Nutr Res 20: 439-443.

7. Resnicow K, Davis-Hearn M, Smith M, Baranowski T, Lin LS, et al. (1997) Socialcognitive predictors of fruit and vegetable intake in children. Health Psychology 16: 272-276.

8. Blanchette L, Brug J (2005) Determinants of fruit and vegetable consumption among 6-12-year-old children and effective interventions to increase consumption. J Hum Nutr Diet 18: 431-443.

9. Rasmussen M, Krølner R, Klepp KI, Lytle L, Brug J, et al. (2006) Determinants of fruit and vegetable consumption among children and adolescents: systematic review of the literature. Int J Behav Nutr Phys Act 3: 22

10. Rozin P, Vollmecke TA (1986) Food likes and dislikes. Annu Rev Nutr 6: 433-456.
[Crossref]

11. Looy H, Weingarten HP (1992) Facial expressions and genetic sensitivity to 6-n-propylthiouracil predict hedonic response to sweet. Physiol Behav 52: 75-82. [Crossref]

12. Beauchamp GK, Mennella JA (2009) Early flavor learning and its impact on later feeding behavior. Pediatr Gastroenterol Hepatol Nutr 48: S25-S30.

13. Steiner JE (1979) Human facial expressions in response to taste and smell stimulation. Adv Child Dev Behav 13: 257-295. [Crossref]

14. Rosenstein D Oster H (1988) Differential facial responses to four basic tastes in newborns. Child Dev 59: 1555-1568. [Crossref]

15. Mennella JA, Beauchamp GK (1998) Early flavor experiences: research update. Nutr Rev 56: 205-211. [Crossref]

16. Ganchrow JR, Mennella JA (2003) The ontogeny of human flavor perception. In: Doty RL (Ed.), Handbook of olfaction and gustation, New York: Marcel Dekker pp: 823-846.

17. Drewnowski A, Rock CL (1995) The influence of genetic taste markers on food acceptance. Am J Clin Nutr 62: 506-511. [Crossref]

18. Glendinning JI (1994) Is the bitter rejection response always adaptive? Physiol Behav 56: 1217-1227. [Crossref]

19. Hladik CM, Pasquet P, Simmen B (2002) New perspectives on taste and primate evolution: the dichotomy in gustatory coding for perception of beneficient versus noxoius substances as supported b ycorrelations among human thresholds. Am J Phys Anthropol 117: 342-348.

20. Behrens M, Meyerhof W (2006) Bitter taste receptors and human bitter taste perception. Cell Mol Life Sci 63: 1501-1509. [Crossref]

21. De Belloy M (2007) French children don’t get fat. La Vergne: Lightning Source.

22. Reed DR, Tanaka T, McDaniel AH (2006) Diverse tastes: Genetics of sweet and bitter perception. Physiol Behav 88: 215-226. [Crossref]

23. Rao DC, Morton NE (1977) Residual family resemblance for PTC taste sensitivity. Hum Genet 36: 317-320. [Crossref]

24. Guo SW, Reed DR (2001) The genetics of phenylthiocarbamide perception. Ann Hum Biol 28: 111-142. [Crossref]

25. United States' Department of Energy (2009) Human genome project information.

26. Kim UK, Drayna D (2005) Genetics of individual differences in bitter taste perception: lessons from the PTC gene. Clin Genet 67: 275-280. [Crossref]

27. Drayna D (2005) Human taste genetics. Annu Rev Genomics Hum Genet 6: 217-235. [Crossref]

28. Tordoff MG (2008) Gene discovery and the genetic basis of calcium consumption. Physiol Behav 94: 649-659. [Crossref]

29. Tordoff MG, Shao H, Alarcón LK, Margolskee RF, Mosinger B, et al. (2008) Involvement of T1R3 in calcium-magnesium taste. Physiol Genomics 34: 338-348. [Crossref]

30. Tordoff MG, Sandell MA (2009) Vegetable bitterness is related to calcium content. Appetite 52: 498-504. [Crossref]

31. Bachmanov AA, Beauchamp GK (2007) Taste receptor genes. Annu Rev Nutr 27: 389414. [Crossref]

32. Ishii S, Misaka T, Kishi M, Kaga T, Ishimaru Y, et al. (2009) Acetic acid activates PKD1L3-PKD2L1 channel--a candidate sour taste receptor. Biochem Biophys Res Commun 385: 346-350. [Crossref]

33. Laugerette F, Gaillard D, Passilly-Degrace P, Niot I, Besnard P (2007) Do we taste fat? Biochimie 89: 265-269. [Crossref]

34. Kim UK, Breslin PA, Reed D, Drayna D (2004) Genetics of human taste perception. $J$ Dent Res 83: 448-453. [Crossref]

35. Bartoshuk LM, Duffy VB, Miller IJ (1994) PTC/PROP tasting: anatomy, psychophysics, and sex effects. Physiol Behav 56: 1165-1171. [Crossref]

36. Gayathri Devi A, Henderson SA, Drewnowski A (1997) Sensory acceptance of Japanese green tea and soy products is linked to genetic sensitivity to 6-n-propylthiouracil. Nutr Cancer 29: 146-151. [Crossref]

37. Drewnowski A, Henderson SA, Levine A, Hann C (1999) Taste and food preferences as predictors of dietary practices in young women. Public Health Nutr 2: 513-519. [Crossref] 
Domínguez PR (2017) Insights into the impact of genetic variation in bitter taste sensitivity on young children's acceptance of vegetables and body mass index: an update until 2010

38. Drewnowski A, Henderson SA, Barratt-Fornell A (2001) Genetic taste markers and food preferences. Drug Metab Dispos 29: 535-538. [Crossref]

39. Tanaka T, Reed DR, Ordovas JM (2008) Taste as the gatekeeper of personalized nutrition. In Kok F, Bowman L, Desiere F (Eds.) Personalized nutrition: principles and applications. Boca Raton, FL: Taylor \& Francis Group pp: 115-133.

40. Tepper BJ, White EA, Koelliker Y, Lanzara C, d'Adamo P, et al. (2009) Genetic variation in taste sensitivity to 6-n-propylthiouracil and its relationship to taste perception and food selection. Ann N Y Acad Sci 1170: 126-139. [Crossref]

41. Goldstein GL, Daun H, Tepper BJ (2007) Influence of PROP taster status and maternal variables on energy intake and body weight of pre-adolescents. Physiol Behav 90: 809817. [Crossref]

42. Duffy VB, Bartoshuk LM (2000) Food acceptance and genetic variation in taste. $J \mathrm{Am}$ Diet Assoc 100: 647-655. [Crossref]

43. Garcia-Bailo B, Toguri C, Eny KM, El-Sohemy A (2009) Genetic variation in taste and its influence on food selection. OMICS 13: 69-80. [Crossref]

44. Mojet J, Christ-Hazelhof E, Heidema J (2001) Taste perception with age: generic or specific losses in threshold sensitivity to the five basic tastes? Chem Senses 26: 845860. [Crossref]

45. Segovia C, Hutchinson I, Laing DG, Jinks AL (2002) A quantitative study of fungiform papillae and taste pore density in adults and children. Dev Brain Res 138: 135-146.

46. Whissel-Buechy D (1990) Effects of age and sex on taste sensitivity to phenylthiocarbamid (PTC) in the Berkeley Guidance sample. Chemical Senses 15: 3957.

47. Schiffman SS, Gatlin LA, Frey AE, Heiman SA, Stagner WC, et al. (1994) Taste perception of bitter compounds in young and elderly persons: relation to lipophilicity of bitter compounds. Neurobiol Aging 15: 743-750. [Crossref]

48. Navarro-Allende A, Khataan N, El-Sohemy A (2008) Impact of genetic and environmental determinants of taste with food preferences in older adults. $J$ Nutr Elder 27: 267-276. [Crossref]

49. Mennella JA, Pepino MY, Reed DR (2005) Genetic and environmental determinants of bitter perception and sweet preferences. Pediatrics 115: e216-222. [Crossref]

50. Gibson EL, Bruston JM (2007) Learned Influences on appetite, food choice, and intake: evidence in human beings. Appetite and Body Weight 2007: 271-300.

51. Baxter IA, Schroder MJA (1997) Vegetable consumption among Scottish children: a review of the determinants and proposed strategies to overcome low consumption. British Food Journal 99: 380-387.

52. Drewnowski A, Henderson SA, Shore AB (1997a) aste responses to naringin, a flavonoid, and the acceptance of grapefruit juice are related to genetic sensitivity to 6-n-propylthiouracil. Am J Clin Nutr 66: 391-397.

53. Lamb MW, Ling BC (1946) An analysis of food consumption and preferences of nursery school children. Child Dev 17: 187-217. [Crossref]

54. Harper R (1963) Some attitudes to vegetables, and their implications. Nature 200: 1418. [Crossref]

55. Gibson EL, Wardle J, Watts CJ (1998) Fruit and vegetable consumption, nutritional knowledge and beliefs in mothers and children. Appetite 31: 205-228. [Crossref]

56. Visser J, Kroeze JH, Kamps WA, Bijleveld CM (2000) Testing taste sensitivity and aversion in very young children: development of a procedure. Appetite 34: 169-176. [Crossref]

57. Wardle J, Sanderson S, Leigh Gibson E, Rapoport L (2001) Factor-analytic structure of food preferences in four-year-old children in the UK. Appetite 37: 217-223. [Crossref]

58. Kalmus H (1971) Genetics of taste. In L.M. Beidler (Ed.), Handbook of sensory Physiology New York: Springer-Verlag pp: 165-179.

59. Jerzsa-Latta M, Krondl M, Coleman P (1990) Use and perceived attributes of cruciferous vegetables in terms of genetically-mediated taste sensitivity. Appetite 15 : 127-134. [Crossref]

60. Engel E, Martin N, Issanchou S (2006) Sensitivity to allyl, isothiocyanate, dimethyl trisulfide, sinigrin, and cooked cauliflower consumption. Appetite 46: 263-269.

61. Aranceta J, Pérez-Rodrigo C, Dalmau G, Lama R, Martín M, et al. (2008) El comedor escolar: situación actual y guía de recomendaciones. Anales de Pediatría (Barcelona) 69: $72-88$.

62. Lorson BA, Melgar-Quinonez HR, Taylor CA (2009) Correlates of fruit and vegetable intakes in US children. J Am Diet Assoc 109: 474-478. [Crossref]
63. Krebs-Smith SM, Cook A, Subar AF, Cleveland L, Friday J, et al. (1996) Fruit and vegetable intakes of children and adolescents in the United States. Arch Pediatr Adolesc Med 150: 81-86. [Crossref]

64. Johnson RK, Kennedy E (2000) The 2000 Dietary Guidelines for Americans: what are the changes and why were they made? J Am Diet Assoc 100: 769-774.

65. Yngve A, Wolf A, Poortvliet E, Elmadfa I, Brug J, et al. (2005) Fruit and vegetable intake in a sample of 11-year-old children in 9 European countries: The Pro Children Cross-sectional Survey. Ann Nutr Metab 49: 236-245.

66. Lakkakula AP, Zanovec M, Silverman L, Murphy E, Tuuri G (2008) Black children with high preferences for fruits and vegetables are at less risk of being at risk of overweight or overweight. J Am Diet Assoc 108: 1912-1915. [Crossref]

67. Weker H (2006) Simple obesity in children. A study on the role of nutritiona factors. Med Wieku Rozwoj 10: 3-191. [Crossref]

68. WHO (2009) Promoting fruit and vegetable consumption arround the world. World Health Organisation.

69. Maynard M, Gunnell D, Emmett P, Frankel S, Davey Smith G (2003) Fruit, vegetables, and antioxidants in childhood and risk of adult cancer: the Boyd Orr cohort. J Epidemiol Community Health 57: 218-225. [Crossref]

70. Mikkilä V, Räsänen L, Raitakari OT, Pietinen P, Viikari J (2004) Longitudinal changes in diet from childhood into adulthood with respect to risk of cardiovascular diseases: The Cardiovascular Risk in Young Finns Study. Eur J Clin Nutr 58: 1038-1045.

71. Ness AR, Maynard M, Frankel S, Smith GD, Frobisher C, et al. (2005) Diet in childhood and adult cardiovascular and all cause mortality: the Boyd Orr cohort. Heart 91: 894 898. [Crossref]

72. Nicklaus S, Boggio V, Chabanet C, Issanchou S (2005) A prospective study of food variety seeking in childhood, adolescence and early adult life. Appetite 44: 289-297. [Crossref]

73. Pearson N, Biddle SJ, Gorely T (2009) Family correlates of breakfast consumption among children and adolescents. A systematic review. Appetite 52: 1-7. [Crossref]

74. Douglas L (1998) Children's choice. Nut Food Sci 1: 14-18.

75. Knai C, Pomerleau J, Lock K, McKee M (2006) Getting children to eat more fruit and vegetables: a systematic review. Prev Med 42: 85-95. [Crossref]

76. Warren E, Parry O, Lynch R, Murphy S (2008) 'If I don't like it then I can choose what I want': Welsh school children's accounts of preference for and control over food choice. Health Promot Int 23: 144-151. [Crossref]

77. Skinner JD, Bounds W, Carruth BR, Morris M, Ziegler P (2004) Predictors of children's body mass index: a longitudinal study of diet and growth in children aged 2-8 y. Int $J$ Obes Relat Metab Disord 28: 476-482. [Crossref]

78. Anliker JA, Bartoshuk L, Ferris AM, Hooks LD (1991) Children's food preferences and genetic sensitivity to the bitter taste of 6-n-propylthiouracil (PROP). Am J Clin Nutr 54: 316-320. [Crossref]

79. Fox AL (1932) The Relationship between Chemical Constitution and Taste. Proc Natl Acad Sci USA 18: 115-120. [Crossref]

80. Berlinerblau J (1884) Über die Einwirkung von Chlorcyan auf Ortho- und auf ParaAmidophenetol. Journal für Praktische Chemie 30: 97-115.

81. Blakeslee AF, Fox AL (1932) Our different taste worlds: P. T. C. as a Demonstration of Genetic Differences in taste. J Hered 23: 97-107.

82. Snyder LH (1931) Inherited taste deficiency. Science 74: 151-152. [Crossref]

83. Blakeslee AF (1931) The genetic view-point. Science 73: 571-577. [Crossref]

84. Bartoshuk LM, Duffy VB, Reed D, Williams A (1996) Supertasting, earaches and head injury: genetics and pathology alter our taste worlds. Neurosci Biobehav Rev 20: 79-87.

85. Blakeslee AF (1932) Genetics of Sensory Thresholds: Taste for Phenyl Thio Carbamide. Proc Natl Acad Sci USA 18: 120-130. [Crossref]

86. Merton B (1958) Taste sensitivity to PTC in 60 Norwegian families with 176 children. Confirmation of the hypothesis of single gene inheritance. Acta genetica et statistica medica 8: 114-128.

87. Morton CC, Cantor RM, Corey LA, Nance WE (1981) A genetic analysis of taste threshold for phenylthiocarbamide. Acta Genet Med Gemellol (Roma) 30: 51-57. [Crossref]

88. DAS SR (1958) Inheritance of the P.T.C. taste character in man: an analysis of 126 Rarhi Bráhmin families of West Bengal. Ann Hum Genet 22: 200-212. [Crossref] 
Domínguez PR (2017) Insights into the impact of genetic variation in bitter taste sensitivity on young children's acceptance of vegetables and body mass index: an update until 2010

89. Olson JM, Boehnke M, Neiswanger K, Roche AF, Siervogel RM (1989) Alternative genetic models for the inheritance of the phenylthiocarbamide taste deficiency. Genet Epidemiol 6: 423-434. [Crossref]

90. Chautard-Freire-Maia EA (1974) Linkage relationships between 22 autosomal markers. Ann Hum Genet 38: 191-198. [Crossref]

91. Conneally PM, Dumont-Driscoll M, Huntzinger RS, Nance WE, Jackson CE (1976) Linkage relations of the loci for Kell and phenylthiocarbamide taste sensitivity. Hum Hered 26: 267-271. [Crossref]

92. Anne-Spence M, Falk CT, Neiswanger K, Field LL, Marazita ML, et al. (1984) Estimating the recombination frequency for the PTC-Kell linkage. Hum Genet 67: 183186. [Crossref]

93. Reed DR, Nanthakumar E, North M, Bell C, Bartoshuk LM, et al. (1999) Localization of a gene for bitter-taste perception to human chromosome 5p15. Am J Hum Genet 64: 1478-1480. [Crossref]

94. Drayna D, Coon H, Kim UK, Elsner T, Cromer K, et al. (2003) Genetic analysis of a complex trait in the Utah Genetic Reference Project: a major locus for PTC taste ability on chromosome 7q and a secondary locus on chromosome 16p. Human Genetics 112: 567-572.

95. Kim UK, Jorgenson E, Coon H, Leppert M, Risch N, et al. (2003) Positional cloning of the human quantitative trait locus underlying taste sensitivity to phenylthiocarbamide. Science 299: 1845-2848.

96. Bufe B, Breslin PAS, Kuhn C, Reed DR, Tharp CD, et al. (2005) The molecular basis of individual differences in phenylthiocarbamide and propylthiouracil bitterness perception. Curr Biol 15: 322-327.

97. Reed DR (2004) Progress in human bitter phenylthiocarbamide. In: Prescott J, Tepper BJ (Eds.), Taste sensitivity, New York: Marcel Dekker pp: 43-63.

98. Wooding S, Kim UK, Bamshad MJ, Larsen J, Jorde LB, et al. (2004) Natural selection and molecular evolution in PTC, a bitter-taste receptor gene. Am J Hum Genet 74 : 637-646. [Crossref]

99. Sandell MA, Breslin PA (2006) Variability in a taste-receptor gene determines whether we taste toxins in food. Curr Biol 16: R792-794. [Crossref]

100. Adler E, Hoon MA, Mueller KL, Chandrashekar J, Ryba NJ, et al. (2000) A novel family of mammalian taste receptors. Cell 100: 693-702. [Crossref]

101. epper BJ (2008) Nutritional implications of genetic taste variation: the role of PROP sensitivity and other taste phenotypes. Annu Rev Nutr 28: 367-388. [Crossref]

102. eherns M, Brockhoff A, Kuhn Ch, Bufe B, Winnig M, et al. (2004) The human taste receptor hTAS2R14 responds to a variety of different bitter compounds. Biochem Biophys Res Commun 319: 479-485.

103. Matsunami H, Montmayeur JP, Buck LB (2000) A family of candidate taste receptors in human and mouse. Nature 404: 601-604. [Crossref]

104. Conte C, Ebeling M, Marcuz A, Nef P, Andres-Barquin PJ (2002) Identification and characterization of human taste receptor genes belonging to the TAS2R family. Cytogenet Genome Res 98: 45-53.

105. Drewnowski A (2001) The science and complexity of bitter taste. Nutr Rev 59: $163-$ 169. [Crossref]

106. Tepper BJ (1998) 6-n-Propylthiouracil: a genetic marker for taste, with implications for food preference and dietary habits. Am J Hum Genet 63: 1271-1276. [Crossref]

107. Keller KL, Tepper BJ (2004) Inherited taste sensitivity to 6-n-propylthiouracil in diet and body weight in children. Obes Res 12: 904-912. [Crossref]

108. Lumeng JC, Cardinal TM, Sitto JR, Kannan S (2008) Ability to taste 6-n-propylthiouracil and BMI in low-income preschool-aged children. Obesity (Silver Spring) 16: 1522-1528. [Crossref]

109. Yeomans MR, Prescott J, Gould NJ (2009) Acquired hedonic and sensory characteristics of odours: influence of sweet liker and propylthiouracil taster status. $Q$ J Exp Psychol (Hove) 23: 1-17

110. Bhasin MK (2006) Genetics of castes and tribes of India: taste sensitivity. Int J Hum Genet 6: 145-151.

111. Delwiche JF, Buletic Z, Breslin BA (2001) Covariation in individuals' sensitivities to bitter compounds: evidence supporting multiple receptor/transduction mechanisms. Perception and Psychophysics 63: 761-776.

112. Bufe B, Hofmann T, Krautwurst D, Raguse JD, Meyerhof W (2002) The human TAS2R16 receptor mediates bitter taste in response to beta-glucopyranosides. Nat
Genet 32: 397-401. [Crossref]

113. Soranzo N, Bufe B, Sabeti PC, Wilson JF, Weale ME, et al. (2005) Positive selection on a high-sensitivity allele of the human bitter-taste receptor TAS2R16. Curr Biol 15: 1257-1265. [Crossref]

114. Sausenthaler S, Kohlhammer Y, Schäffer L, Heinrich J, Koletzko S, et al. (2006) Genetically determined lower bitter-taste sensitivity in Africans? Br J Nutr 96: 607608. [Crossref]

115. Shi P, Zhang J, Yang H, Zhang P (2003) Adaptive diversification of bitter taste receptor genes in Mammalian evolution. Mol Biol Evol 20: 805-814.

116. Lalueza-Fox C, Gigli E, de la Rasilla M, Fortea J, Rosas A (2009) Bitter taste perception in Neanderthals through the analysis of the TAS2R38 gene. Biol Lett 5 : 809-811. [Crossref]

117. Barnicot NA, Harris H, Kalmus H (1951) Taste thresholds of further eighteen compounds and their correlation with P.T.C thresholds. Ann Eugen 16: 119-128. [Crossref]

118. Harris H, Kalmus H (1949) Chemical specificity in genetical differences of taste sensitivity. Ann Eugen 15: 32-45. [Crossref]

119. Fischer R, Griffin F (1964) Pharmacogenetic aspects of gustation. Arzneimittelforschung 14: 673-686. [Crossref]

120. Lawless HT (1980) A comparison of different methods used to assess sensitivity to the taste of phenylthiocarbamide (PTC). Chemical Senses 5: 247-256.

121. Reedy FE, Bartoshuk LM, Miller IJ, Duffy VB, Yanagisawa K (1993) Relationship among papillae, taste pores and 6-n-propylthiouracil (PROP) suprathreshold taste sensitivity. Chemical Senses 18: 618-619.

122. Reed DR, Bartoshuk LM, Duffy V, Marino S, Price A (1995) Propylthiouracil tasting: determination of underlying threshold distributions using maximum likelihood. Chemical Senses 20": 529-533.

123. Prutkin J, Fisher EM, Etter L, Fast K, Gardner E, et al. (2000) Genetic variation and inferences about perceived taste intensity in mice and men. Physiol Behav 69: 161173. [Crossref]

124. Bartoshuk LM (2000) Psychophysical advances aid the study of genetic variation in taste. Appetite 34: 105. [Crossref]

125. Bartoshu LM (2000b) Comparing sensory experiences across individuals: recent psychophysical advances illuminate genetic variation in taste perception. Chemical Senses 25: 447-460.

126. Bartoshuk LM (1980) Separate worlds of taste. Psychology Today 14: 48-63.

127. Keller KL, Steinmann L, Nurse RJ, Tepper BJ (2002) Genetic taste sensitivity to 6-n-propylthiouracil influences food preference and reported intake in preschool children. Appetite 38: 3-12.

128. Whissell-Buechy D, Wills C (1989) Male and female correlations for taster (P.T.C.) phenotypes and rate of adolescent development. Ann Hum Biol 16: 131-146. [Crossref]

129. Tepper BJ, Christensen CM, Cao J (2001) Development of brief methods to classify individuals by PROP taster status. Physiol Behav 73: 571-577. [Crossref]

130. Bartoshuk LM, Duffy VB, Green BG, Hoffman HJ, Ko CW, et al. (2004) Valid across-group comparisons with labeled scales: the gLMS versus magnitude matching. Physiol Behav 82: 109-114.

131. Snyder DJ, Prescott J, Bartoshuk LM (2006) Modern psychophysics and the assessment of human oral sensation. Adv Otorhinolaryngol 63: 221-241. [Crossref]

132. Drewnowsky A, Kristal A, Cohen J (2001b) Genetic taste responses to 6-n-Propylthiouracil among adults: a screening tool for epidemiological studies. Chemical Senses 26: 483-489.

133. Boughter JD Jr, Bachmanov AA (2007) Behavioral genetics and taste. BMC Neurosci 8: S3. [Crossref]

134. Stevens SS (1969) Sensory scales of taste inensity. Perception and Psychophysics 6: $302-308$.

135. Turnbull B, Matisoo-Smith E (2002) Taste sensitivity to 6-n-propylthiouracil predicts acceptance of bitter-tasting spinach in 3-6-y-old children. Am J Clin Nutr 76: 1101 1105. [Crossref]

136. Maier AS (2007) Influence des pratiques d'allaitement et de sevrage sur l'acceptation de flaveurs nouvelles chez le jeune enfant: variabilité intra-et inter-régionale. Doctora Thesis. Paris: Ecole doctorale des Sciences de la Vie et de la Santé. 
Domínguez PR (2017) Insights into the impact of genetic variation in bitter taste sensitivity on young children's acceptance of vegetables and body mass index: an update until 2010

137. Prescott J, Ripandelli N, Wakeling I (2001) Binary taste mixture interactions in prop non-tasters, medium-tasters and super-tasters. Chem Senses 26: 993-1003. [Crossref]

138. Hall MJ, Bartoshuk LM, Cain WS, Stevens JC (1975) PTC taste blindness and the taste of caffeine. Nature 253: 442-443. [Crossref]

139. Leach EJ, Noble AC (1986) Comparison of bitterness of caffeine and quinine by a time-intensity procedure. Chemical Senses 11: 339-345.

140. Mela DJ (1989) Bitter taste intensity: the effect of tastant and thiourea taster status. Chemical Senses 14: 131-135.

141. Yokomukai Y, Cowart BJ, Beauchamp GK (1993) Individual differences in sensitivity to bitter-tasting substances. Chemical Senses 18: 669-681.

142. Bartoshuk LM (1979) Bitter taste of saccharin related to the genetic ability to taste the bitter substance 6-n-propylthiouracil. Science 205: 934-935. [Crossref]

143. Bartoshuk LM, Rifkin B, Marks LE, Hooper JE (1988) Bitterness of KCL and benzoate: related to PTC/PROP. Science 205: 146-151.

144. Yackinous CA, Guinard JX (2002) Relation between PROP (6-n-propylthiouracil) taster status, taste anatomy and dietary intake measures for young men and women. Appetite 38: 201-209. [Crossref]

145. Pronin AN, Xu H, Tang H, Zhang L, Li Q, et al. (2007) Specific alleles of bitter receptor genes influence human sensitivity to the bitterness of aloin and saccharin. Current Biology 17: 1403-1408.

146. Blakeslee AF, Salmon MR (1935) Genetics of sensory thresholds: individual taste reactions for different substances. Proc Natl Acad Sci USA 21: 84-90.

147. Gent JF, Bartoshuk LM (1983) Sweetness of sucrose, neohesperidin dihydrochalcone, and saccharin is related to the genetic ability to taste the bitter substance 6-n-propylthiouracil. Chemical Senses 7:" 265-272.

148. Drewnowski A, Henderson SA, Shore AB, Barratt-Fornell A (1997) Nontasters, tasters, and supertasters of 6-n-propylthiouracil (PROP) and hedonic response to sweet. Physiol Behav 62: 649-655. [Crossref]

149. Prutkin JM, Fast K, Lucchina LA, Snyder DJ, Bartoshuk LM (1999) Spatial taste testing and genetic taste variation. Chemical Senses 24:" 604.

150. Bartoshuk LM, Duffy VB, Lucchina LA, Prutkin J, Fast K (1998) PROP (6-n-propylthiouracil) supertasters and the saltiness of $\mathrm{NaCl}$. Ann N Y Acad Sci 855: 793-796. [Crossref]

151. Tepper BJ, Nurse RJ (1997) Fat perception is related to PROP taster status. Physio Behav 61: 949-954. [Crossref]

152. Kirkmeyer SV, Tepper BJ (2005) Consumer reactions to creaminess and genetic sensitivity to 6-n-propylthiouracil: a multidimensional study. Food Quality and Preference 16: 545-556.

153. Prescott J, Soo J, Campbell H, Roberts C (2004) Responses of PROP taster groups to variations in sensory qualities within foods and beverages. Physiol Behav 82: 459469. [Crossref]

154. Karrer T, Bartoshuk L (1991) Capsaicin desensitization and recovery on the human tongue. Physiol Behav 49: 757-764. [Crossref]

155. Tepper BJ, Nurse RJ (1998) PROP taster status is related to fat perception and preference. Ann N Y Acad Sci 855: 802-804. [Crossref]

156. Bartoshuk L, Conner E, Grubin D, Barrer T, Kochenbach K, et al. (1993) PROP supertasters and the perception of ethyl alcohol. Chemical Senses 18: 526-527.

157. Ly A, Drewnowski D (2001) PROP (6-n-Propylthiouracil) Tasting and Sensory Responses to Caffeine, Sucrose, Neohesperidin Dihydrochalcone and Chocolate. Chemical Senses 26: 41-47.

158. Duffy VB, Davidson AC, Kidd JR, Kidd KK, Speed WC, et al. (2004) Bitter receptor gene (TAS2R38), 6-n-propylthiouracil (PROP) bitterness and alcohol intake. Alcohol Clin Exp Res 28: 1629-1637. [Crossref]
159. Fischer R, Griffin F, England S, Garn SM (1961) Taste thresholds and food dislikes. Nature 191: 1328. [Crossref]

160. Glanville EV, Kaplan AR (1965) Food preferences and sensitivity to taste for bitter compounds. Nature 205:" 851-853.

161. Korslund MK, Eppright ES (1963) Taste sensitivity and eating behavior of preschool children. J Home Econ 59: 168-170.

162. Tepper BJ (1999) Does genetic taste sensitivity to PROP influence food preferences and body weight? Appetite 32: 422. [Crossref]

163. Lindgren HC (1962) Age as a variable in aversion toward food and occupations. $J$ Consult Psychol 26: 101-102. [Crossref]

164. Pao E, Fleming KH, Guenther PM, Mickle SJ (1982) Foods commonly eaten by individuals: amount per day and per eating occasion. United States Department of Agriculture, Human Nutrition Service, Home Economics Research Report No. 44. Washington, DC: U.S. Government Printing Office.

165. Rolls BJ (1999) Do chemosensory changes influence food intake in the elderly? Physiol Behav 66: 193-197. [Crossref]

166. Birch LL, Marlin DW (1982) I don't like it; I never tried it: effects of exposure on two-year-old children's food preferences. Appetite 3: 353-360. [Crossref]

167. Birch LL (1999) Development of food preferences. Annu Rev Nutr 19: 41-62. [Crossref]

168. Wardle J, Herrera ML, Cooke L, Gibson EL (2003) Modifying children's food preferences: the effects of exposure and reward on acceptance of an unfamiliar vegetable. Eur J Clin Nutr 57: 341-348. [Crossref]

169. Forestell CA, Mennella JA (2007) Early determinants of fruit and vegetable acceptance. Pediatrics 120: 1247-1254. [Crossref]

170. Drewnowski A, Henderson SA, Cockroft JE (2007) Genetic sensitivity to 6-n-propylthiouracil has no influence on dietary patterns, body mass indexes, or plasma lipid profiles of women. J Am Diet Assoc 107: 1340-1348.

171. Fischer R, Griffin F (1961) "Taste-blindness" and variations in taste-threshold in relation to thyroid metabolism. J Neuropsychiatr 3: 98-104. [Crossref]

172. Fischer R, Griffin F, Kaplan AR (1963) Taste thresholds, cigarette smoking, and food dislikes. Med Exp Int J Exp Med 9: 151-167. [Crossref]

173. Donaldson LF, Bennett L, Baic S, Melichar JK (2009) Taste and weight: is there a link? Am J Clin Nutr 90: 800S-803S. [Crossref]

174. Fushan AA, Simons ChT, Slack JP, Manichaikul A, Drayna D (2009) Allelic Polymorphism within the TAS1R3 Promoter Is Associated with Human Taste Sensitivity to Sucrose. Curr Biol 19: 1288-1293.

175. Bell KI, Tepper BJ (2006) Short-term vegetable intake by young children classified by 6-n-propylthoiuracil bitter-taste phenotype. Am J Clin Nutr 84: 245-251.

176. Heany GR, Fenwick RK (1980) Glucosinates in Brassicca vegetables. Analysis of 22 varieties of Brussels sprout (Brassica oleracea var. gemmifera). J Sci Food Agr 31: 785-793.

177. Fenwick GR, Heaney RK, Mullin WJ (1983) Glucosinolates and their breakdown products in food and food plants. Crit Rev Food Sci Nutr 18: 123-201. [Crossref]

178. Zhang Y, Thalalay P, Cho CG, Posner GH (1992) A major inducer of anticarcinogenic protective enzymes from broccoli: isolation and elucidation of structure. Proc Natl Acad Sci USA 89: 2399-2403.

179. Drewnowski A, Gomez-Carneros C (2000) Bitter taste, phytonutrients, and the consumer: a review. Am J Clin Nutr 72: 1424-1435. [Crossref]

180. Baranowski JC, Baranowski T, Beltran A, Watson KB, Jago R, et al. (2009) 6-n-Propylthiouracil sensitivity and obesity status among ethnically diverse children. Public Health Nutrition, In Press.

Copyright: (C2017 Domínguez PR. This is an open-access article distributed under the terms of the Creative Commons Attribution License, which permits unrestricted use, distribution, and reproduction in any medium, provided the original author and source are credited. 